ASIMETRIS: JURNAL PENDIDIKAN MATEMATIKA DAN SAINS

$$
\text { p-ISSN } 2721 \text { - 8724, e-ISSN } 2722 \text { - } 0214
$$

Website Jurnal: http://journal.umuslim.ac.id/index.php/asm/

\begin{aligned} & Info Artikel: Direvisi pada 13 Oktober 2021 \\ & Disubmit pada 9 Oktober 2021 Diterima pada 18 Oktober 2021 \\ & Direview pada 10 Oktober 2021 Tersedia secara daring pada 28 Oktober 2021 \\ & \hline\end{aligned}

\title{
PENERAPAN MODEL PEMBELAJARAN LEARNING TOGETHER UNTUK MENINGKATKAN PRESTASI SISWA KELAS X TKJ SMK NEGERI 1 JEUMPA
}

\author{
Husna \\ SMK Negeri 1 Jeumpa, Bireuen, Indonesia \\ Alamat email: ina84.usman@gmail.com
}

\begin{abstract}
ABSTRAK. Tujuan penelitian ini adalah untuk mengetahui peningkatan Prestasi siswa kelas $X$ TKJ materi Trigonometri pelajaran matematika dengan menggunakan Model Learning Together. Pendekatan yang digunakan adalah pendekatan kualitatif dengan desain Penelitian Tindakan Kelas. Subjek penelitian ini adalah siswa kelas X TKJ Tahun Pelajaran 2020/2021 yang berjumlah 25 orang siswa, untuk memperoleh data penulis menggunakan teknik tes dan non tes. Berdasarkan hasil analisis data dengan cara membandingkan hasil observasi dan tes pada siklus I dan siklus II. Hasil penelitian menunjukkan bahwa peningkatan dari siklus I ke siklus II sebanyak $28,48 \%$. Dimana pada siklus I ketuntasan yang diperoleh $62 \%$ dengan jumlah siswa 13 orang, sedangkan pada siklus II jumlah persentase ketuntasan adalah $90,48 \%$ dengan jumlah siswa menngkat mejadi 19 orang yang tuntas dalam belajar. Jadi, dari hasil siklus I dan siklus II, penelitian sudah selesai, karena ketidak tuntasan pada siklus I sudah diperbaiki pada siklus II. Oleh karena itu, penerapan model pembelajaran Kooperatif Learning model Learning Together dapat meningkatkan hasil belajar mata pelajaran matematika khususnya kompetensi dasar Hubungan Fungsi Trigonometri dan Identitas Trigonometri bagi siswa kelas X TKJ Semester 2 SMK Negeri 1 Jeumpa Tahun Pelajaran 2020/2021.
\end{abstract}

Kata Kunci: Learning Together; Prestasi Siswa; Trigonometri

ABSTRACT. The purpose of this study was to determine the increase in the achievement of class X TKJ students in the Trigonometry material in mathematics by using the Learning Together Model. The approach used is a qualitative approach with Classroom Action Research design. The subjects of this study were students of class X TKJ in the 2020/2021 academic year, totaling 25 students, to obtain the author's data using test and non-test techniques. Based on the results of data analysis by comparing the results of observations and tests in cycle I and cycle II. The results showed that the increase from cycle I to cycle II was $28.48 \%$. Where in the first cycle of completeness obtained 62\% with the number of students 13 people, while in the second cycle the total percentage of completeness is $90.48 \%$ with the number of students increasing to 19 people who are complete in learning. So, from the results of cycle I and cycle II, the research has been completed, because the incompleteness in cycle I has been corrected in cycle II. Therefore, the application of the Cooperative Learning Learning Together model can improve learning outcomes for mathematics subjects, especially the basic competencies of the Relationship of Trigonometric Functions and Trigonometric Identity for class X TKJ Semester 2 SMK Negeri 1 Jeumpa in the 2020/2021 academic year.

Keyword: Learning Together; Student achievement; Trigonometri

\section{PENDAHULUAN}

Belajar secara sederhana adalah mengamati lingkungan tempat kita berada. Dengan cara mengamati lingkungan dan alam sekitar serta kebiasaan-kebiasan yang dialami, maka dapat dikatakan seseorang telah menjalani proses pembelajaran. Belajar dapat juga diartikan sebagai suatu kegiatan yang dilaksanakan secara berencana dan teratur untuk mendapatkan hasil yang diharapkan. Hal ini sesuai dengan pendapat (Khuloqo. I E, 2017) yang menyatakan bahwa "Belajar merupakan suatu pembelajaran di mana terdapat sebuah proses dari tidak tahu menjadi tahu, tidak 
mengerti menjadi mengerti, tidak bisa menjadi bisa untuk mencapai hasil yang meningkat.

Sedangkan pengertian belajar menurut (Sary, 2015) adalah suatu proses perubahan tindakan yang didasari oleh pengalaman proses belajar mengajar dan berdampak relatif permanen". Dari pendapat tersebut, dapat dikatakan bahwa seseorang yang telah belajar, maka akan berdampak terhadap tingkah lakunya menuju arah yang lebih baik. Dengan adanya dukungan, sarana dan prasarana yang baik terhadap suatu proses pembelajaran maka akan diperoleh suatu prestasi yang baik juga.

Hampir semua siswa dapat mencapai prestasi sebagaimana yang diharapkan, walaupun proses pembelajaran terjadi pada waktu dan guru yang sama. Menurut Arif Gunarso dalam (Istarani \& Pulungan, 2017) "Prestasi belajar adalah suatu pencapaian usaha yang maksimal oleh seseorang setelah adanya proses belajar-mengajar". Jadi hasil belajar yang diperoleh tergantung pada keyakinan untuk berusaha mencapai kesuksesan tersebut.

Sedangkan menurut (Rosyid et al., 2019) mengartikan prestasi belajar yang dinyatakan dalam bentuk simbol, angka, huruf, maupun kalimat yang dapat menghasilkan suatu hasil yang akan dicapai oleh setiap mahasiswa dalam batasan waktu tertentu dan dapat dinyatakan bahwa prestasi belajar merupakan hasil dari suatu kegiatan pembelajaran yang disertai hasil perubahan yang dicapai mahasiswa. Hal ini tentunya telah melampaui rintangan dan hambatan-hambatan yang membentengi keberhasilan tersebut.

Sesuai dengan pendapat di atas (Susanti, 2019) menyatakan bahwa prestasi belajar adalah kemampuan menyelesaikan hal sulit, menguasai, mengungguli, menandingi, dan melampaui mahasiswa lain sekaligus mengatasi hambatan dan mencapai standar yang tinggi. Jadi ketika prestasi anak telah melebihi kawankawan yang lain di kelasnya dikatakan bahwa anak tersebut berprestasi, walaupun terkadang nilainya masih di bawah anak di kelas yang lain.

Adapun faktor-faktor prestasi belajar menurut (Rosyid et al., 2019) adalah : faktor internal yaitu merupakan suatu faktor yang ada pada diri mahasiswa berupa faktor fisiologis ( kesehatan dan keadaan tubuh), faktor psikologis (minat, bakat, inteligensi, emosi, kelelahan, dan cara belajar). Sedangkan faktor eksternal merupakan faktor yang ada pada luar diri mahasiswa yang dipengaruhi oleh lingkungan sekolah, lingkungan keluarga, lingkungan alam, dan lingkungan masyarakat.

Selain faktor tersebut di atas, model pembelajaran yang digunakan oleh guru saat mengajar juga sangat berpengaruh terhadap prestasi belajar siswa. Menurut Arend (Abdurrahman, 2012) model belajar merupakan suatu kerangka konseptual yang mencirikan dan menggambarkan tentang prosedur sistematika dalam pengorganisasian pengalaman belajar guna mencapai kompetensi belajar. Jadi model pembelajaran merupakan suatu perencanaan yang dapat digunakan untuk mendesain pola mengajar secara tatap muka di dalam kelas atau mengatur tutorial, dan untuk menentukan material/perangkat pembelajaran termasuk di dalamnya buku, film, tipe, program-program media komputer, dan kurikulum (sebagai kursus untuk belajar).

Setiap model pembelajaran diarahkan untuk dapat mendesain pembelajaran sehingga dapat membantu siswa untuk mencapai berbagai tujuan. Joyce \& Weil dalam (Rusman, 2018) berpendapat bahwa "model pembelajaran adalah suatu pola atau rencana yang dapat digunakan untuk merancang bahan-bahan pembelajaran membentuk kurikulum (rencana pembelajaran jangka panjang), , dan membimbing pembelajaran di kelas atau lingkungan belajar lain".

Salah satu model pembelajaran yang dapat digunakan untuk membantu guru mencapai tujuan belajar termasuk pada materi trigonometri seperti yang diharapkan adalah Learning together. Pada model ini siswa dikelompokkan ke dalam tim dengan empat sampai lima orang per tim dan heterogen kemampuannya. Dalam suatu kelompok siswa bekerja sama untuk menyelesaikan berbagai gagasan, sebuah produk kelompok, , dan 
membantu satu sama lain dengan beberapa pilihan jawaban, dan meminta bantuan dari teman yang lain sebelum bertanya kepada guru, dan guru memberikan penghargaan kepada kelompok berdasarkan kinerja kelompok lalu menyimpulkan. Hal ini sesuai dengan pendapat (Huda, 2015), model pembelajaran Learning Together siswa ditempatkan dalam kelompok kelompok kecil, yang masing-masing kelompok diminta untuk menghasilkan suatu produk kelompok, kemudian guru bertugas mengawasi kelompok-kelompok ini berdasarkan lima unsur kooperatif.

Adapun langkah-langkah model pembelajaran Learning Together menurut (Huda, 2015) adalah sebagai berkut:

a. Guru menyajikan pelajaran, membentuk kelompok yang terdiri dari 4 sampai 5 orang siswa secara heterogen, masing-masing kelompok menerima lembar tugas untuk bahan diskusi beberapa kelompok mempresentasikan hasil pekerjaannya, pemberian pujian dan penghargaan berdasarkan hasil kerja kelompok.

b. Pada model Learning together siswa dilibatkan secara aktif dalam menemukan konsep sehingga dapat meningkatkan prestasi siswa. Materi yang dapat diajarkan dengan model Learning Together adalah trigonomeri. Materi ini merupakan materi yang sering mendapat hasil yang tidak sesuai dengan yang diharapkan, dimana masih banyak terdapat nilai siswa di bawah ratarata.

Berdasarkan hasil observasi, siswa di SMK kelas X TKJ masih sukar memahami materi Trigonometri pada mata pelajaran matematika, untuk itu penulis telah berusaha menggunakan model pembelajaran Learning Together dan membuat penelitian dengan judul: "Penerapan Model Pembelajaran Learning Together untuk Meningkatkan Prestasi Siswa Kelas X TKJ SMK Negeri 1 Jeumpa".

\section{METODE PENELITIAN}

Penelitian ini menggunakan pendekatan

Penelitian Tindakan Kelas (PTK) yang dilaksanakan pada siswa kelas X SMK Negeri 1 Jeumpa tahun pelajaran 2020/2021. Menurut (Bahri, 2012) Penelitian Tindakan Kelas merupakan sebuah jenis penelitian yang dilaksanakan untuk mengamati kejadian-kejadian dalam kelas untuk memperbaiki praktek dalam pembelajaran agar lebih berkualitas dalam proses sehingga hasil belajarpun menjadi lebih baik. Adapun subyek penelitiannya adalah siswa kelas $X$ TKJ SMK Negeri 1 Jeumpa Bireuen, yang berjumlah 21 orang siswa yang terdiri dari 7 siswa laki-laki dan 14 siswa perempuan.

Pengumpulan data dalam penelitian ini menggunakan teknik tes dan non tes. Tes tertulis digunakan pada akhir siklus I dan siklus II, Sedangkan Teknik non tes meliputi teknik observasi dan dokumentasi. Observasi digunakan pada saat pelaksanaan penelitian tindakan kelas II. Sedangkan teknik dokumentasi digunakan untuk mengumpulkan data khususnya nilai mata pelajaran matematika. Alat pengumpulan data meliputi tes tertulis yang terdiri atas 10 butir soal, sedangkan non tes, meliputi lembar observasi dan dokumen.

Analisis data yang digunakan secara dekskriptif, yang meliputi: a) analisis deskriptif komparatif hasil belajar dengan cara membandingkan hasil belajar pada siklus I dengan siklus II dan membandingkan hasil belajar dengan indikator pada siklus I dan siklus b) analisis deskriptif kualitatif hasil observasi dengan cara membandingkan hasil observasi dan refleksi pada siklus I dan siklus II.

\section{HASIL PENELITIAN DAN PEMBAHASAN}

Berdasarkan hasil penelitian, pembelajaran yang dilakukan oleh peneliti, mengikuti sesuai langakah pembelajaran Learning Together. Pembelajaran dilakukan dengan peneliti hanya mendampingi dan mengarahkan para siswa untuk dapat aktif dalam pembelajaran. Semua siswa dituntut untuk aktif dalam pembelajaran kelompok sehingga dapat menghasilkan pembelajaran yang menyenangkan dan tidak monoton. Disamping itu dalam menyampaikan materi guru tanpa 
menggunakan model pembelajaran. Akan tetapi walaupun sudah menerapkan pembelajaran menggunakan model pembelajaran Learning Together, suasana pembelajaran masih kelihatan kurang maksimal, berdampak pada nilai yang diperoleh siswa kelas X TKJ pada kompetensi dasar Trigonometri sebelum siklus I (pra siklus), dimana terdapat beberapa siswa belum mencapai ketuntasan belajar minimal dalam mempelajari kompetensi dasar tersebut. Hal ini dilihat dari nilai hasil belajar di bawah kriteria ketuntasan minimal (KKM) sebesar 80.

\section{Siklus I}

Berdasarkan hasil tes akhir tindakan, siswa yang mendapatkan skor lebih dari 65 sebanyak 13 orang dan siswa yang mendapatkan skor kurang dari sama dengan 65 sebnayak 8 orang. Setelah dihitung persetase, maka keberhasilan tes akhir tindakan adalah 62 $\%$ dan siswa yang tidak mencapai ketuntasan adalah $38 \%$. Dengan demikan sesua dengan kriteria yang ditetapkan pada tindakan yaitu < 80 $\%$ mendapat skor > 65, maka pelaksanaan tindakan berdasarkan tes akhr belum berhasil.

Tabel 3.1 Analisis kemampuan prestasi siswa siklus I.

\section{Jumlah Persentase Keterangan Siswa}

\begin{tabular}{lll}
\hline $\mathbf{1 3}$ & $62 \%$ & Tuntas \\
\hline $\mathbf{8}$ & $38 \%$ & Tidak Tuntas \\
\hline $\mathbf{2 1}$ & $100 \%$ & Jumlah \\
\hline
\end{tabular}

Dari hasil tes akhir tersebut, diperoleh juga hasil observasi aktivitas guru dan observasi akitivitas siswa. Berikut ini hasil rekapan observasi siswa dan siswa.
Tabel 3.2 Aktivitas Guru Siklus I

\begin{tabular}{lllll}
\hline Kegiatan & $\begin{array}{l}\text { Skor } \\
\text { rata- } \\
\text { rata }\end{array}$ & $\begin{array}{l}\text { Skor } \\
\text { Maksimal }\end{array}$ & Persentase & Kategori \\
\hline I & 34,5 & 50 & $69 \%$ & Kurang \\
\hline II & 34,5 & 50 & $69 \%$ & Kurang \\
\hline Jumlah & 69 & 100 & $69 \%$ & Kurang \\
\hline
\end{tabular}

Dari tabel 3.2 diatas, diperoleh keseluruhan ratarata persentase hasil pengamatan aktivitas guru siklus I yaitu $69 \%$, sehingga dpaat disimpulkan aktivitas guru pada siklus I masih Kurang.

Tabel 3.3 Aktivitas Siswa Siklus I

\begin{tabular}{lllll}
\hline Kegiatan & $\begin{array}{l}\text { Skor } \\
\text { rata- } \\
\text { rata }\end{array}$ & $\begin{array}{l}\text { Skor } \\
\text { Maksimal }\end{array}$ & Persentase & Kategori \\
\hline I & 35 & 50 & $70 \%$ & Kurang \\
\hline II & 34,5 & 50 & $69 \%$ & Kurang \\
\hline Jumlah & 69,5 & 100 & $69,5 \%$ & Kurang \\
\hline
\end{tabular}

Dari tabel 3.3 diatas, diperoleh keseluruhan ratarata persentase hasil pengamatan aktivitas siswa siklus I yaitu $69,5 \%$, sehingga dpaat disimpulkan aktivitas guru pada siklus I masih Kurang.

\section{Siklus II}

Berdasarkan hasil dari pelaksanaan dari siklus I maka kegiatan dilanjutkan dengan adanya lanjutan kegiatan pada siklus II karena pada siklus satu belum berhasil. Hasil tes akhir tindakan, sswa yang mendapatkan skor > 65 sebanyak 19 orang dan siswa yang mendapat skor $<65$ sebanyak 2 orang. Maka persentase pelaksanaan tindakan berdasarkan tes akhir dapat dilihat pada tabel dibawah ini. 
Tabel 3.4 Analisis kemampuan prestasi siswa siklus II.

\begin{tabular}{lll}
$\begin{array}{l}\text { Jumlah } \\
\text { Siswa }\end{array}$ & Persentase & Keterangan \\
\hline $\mathbf{1 9}$ & $90,48 \%$ & Tuntas \\
\hline $\mathbf{2}$ & $9,52 \%$ & Tidak Tuntas \\
\hline $\mathbf{2 1}$ & $100 \%$ & Jumlah \\
\hline
\end{tabular}

Dari tabel 3.4 diatas, menunjukkan bahwa pelaksanaan pembelajaran dengan model pemebelajaran Learning Together terjadi peningkatan dari siklus I ke siklus II. Pada siklus II, terdapat 2 orang yang tidak tuntas dengan persentase ketidak tuntasan sebanyak 9,52\% dari persentase yang tuntas sebanyak $90,48 \%$ dari 19 orang. Jelas terlihat bahwa terjadi peningkatan dari siklus I ke siklus II sebanyak $28,48 \%$.

Dari hasil tes akhir tersebut, diperoleh juga hasil observasi aktivitas guru dan observasi akitivitas siswa. Berikut ini hasil rekapan observasi siswa dan siswa.

Tabel 3.5 Aktivitas Guru Siklus II

\begin{tabular}{lcccc}
\hline Kegiatan & $\begin{array}{l}\text { Skor } \\
\text { rata- } \\
\text { rata }\end{array}$ & $\begin{array}{l}\text { Skor } \\
\text { Maksimal }\end{array}$ & Persentase & Kategori \\
\hline I & 40 & 50 & $80 \%$ & Bagus \\
\hline II & 45 & 50 & $90 \%$ & bagus \\
\hline Jumlah & 85 & 100 & $85 \%$ & bagus
\end{tabular}

Dari tabel 3.2 diatas, diperoleh keseluruhan ratarata persentase hasil pengamatan aktivitas guru siklus II yaitu $85 \%$, sehingga dapat disimpulkan aktivitas guru pada siklus sudah bagus.
Tabel 3.6 Aktivitas Siswa Siklus II

\begin{tabular}{lcccc}
\hline Kegiatan & $\begin{array}{l}\text { Skor } \\
\text { rata- } \\
\text { rata }\end{array}$ & $\begin{array}{l}\text { Skor } \\
\text { Maksimal }\end{array}$ & Persentase & Kategori \\
\hline I & 45 & 50 & $90 \%$ & bagus \\
\hline II & 45 & 50 & $90 \%$ & bagus \\
\hline Jumlah & 90 & 100 & $90 \%$ & bagus
\end{tabular}

Dari tabel 3.3 diatas, diperoleh keseluruhan ratarata persentase hasil pengamatan aktivitas siswa siklus I yaitu 69,5\%, sehingga dpaat disimpulkan aktivitas guru pada siklus I masih Kurang.

Berdasarkan dari dari siklus I dan siklus II, penelitian sudah selesai, karena ketidak tuntasan pada siklus I sudah diperbaiki pada siklus II. Ini terlihat jelas bahwa peningkatan dari siklus I ke siklus II sebnayak 28,48 \% . Dimana pada siklus I ketuntasan yang diperoleh $62 \%$ dengan jumlah siswa 13 orang, sedangkan pada siklus II jumlah persentase ketuntasan adalah $90,48 \%$ dengan jumlah siswa menngkat mejadi 19 orang yang tuntas dalam belajar. Dapat disimpulkan bahwa pembelajaran kooperatif Model Learning Together mampu meningkatkan hasil belajar, khususnya pada kompetensi dasar Hubungan Fungsi Trigonometri dan Identitas trigonometri .

\section{SIMPULAN}

Berdasarkan hasil penelitian dapat disimpulkan bahwa:

1. Model pembelajaran kooperatif Learning Together dapat meningkatkan hasil belajar siswa pada materi trigonometri.

2. Aktivitas siswa pada proses pembelajaran dengan menggunakan model pembelajaran kooperatif Learning Together berada pada kategori baik.

3. Aktivitas guru pada proses pembelajaran dengan menggunakan model pembelajaran kooperatif Learning Together juga berada pada kategori baik 


\section{DAFTAR PUSTAKA}

Abdurrahman, M. (2012). Anak Berkesulitan Belajar: Teori. In Diagnosis, dan Remediasinya, Rineka Cipta, Jakarta.

Bahri, A. (2012). Penelitian Tindakan Kelas. Universitas Muhammadiyah Makasar.

Huda, M. (2015). Cooperative Learning Metode, Teknik, Struktur, dan Model Pembelajaran. Yogyakarta: Pustaka Pelajar Year.

Istarani, \& Pulungan, I. (2017). Ensiklopeda Pendidikan. Media Persada.

Khuloqo. I E. (2017). Belajar dan Pembelajaran. https://pustakapelajar.co.id/buku/belajardan-pembelajaran/

Rosyid, M., Mansyur, M., \& Abdullah, A. (2019). Prestasi Belajar. Literasi Nusantara.

Rusman. (2018). Model-model Pembelajaran Mengembangkan Profesionalisme Guru (Edisi Kedu). Rajawali Pers.

Sary, Y. (2015). Buku Ajar Psikologi Pendidikan Untuk Mahasiswa Umum dan Kesehatan. https://library.unismuh.ac.id/opac/detailopac?id=102651

Susanti, L. (2019). Prestasi Belajar Akademik \& Non Akademik. Literasi Nusantara Abadi. 